\title{
4
}

\section{THE HISTORICITY OF THE REFIGURATION OF SPACES UNDER THE SCRUTINY OF PRE-COVID-19 SÃO PAULO HOMELESS PEDESTRIANS ${ }^{1}$}

\author{
Fraya Frehse
}

\section{The implicitness of historicity}

This chapter aims to contribute to the "refiguration of spaces" approach by critically addressing the concept of historicity on which it relies. Assuming historicity as a "time determination" based on links between past, present, and future events (Weidenhaus 2015, 24), the issue concerns the historicity that underlies this figurational approach to the so-called production of space, which in sociology summarizes the macro- and micro-social processes involved in the generation and/ or regeneration of space as a set of bodily and materially mediated social relations (Frehse 2020, 3-4).

Since Karl Marx's pioneering conceptualization of societal historicity (Weidenhaus 2015, 194), various social scientists have developed their own approaches to the socially specific rhythms of historic change in different societies. If we, against the backdrop of this debate, consider that the refiguration of spaces was conceived as a "diagnosis of the present time" (Knoblauch 2017, 16-17, 381-398) that "makes it possible to explain the dynamics of contemporary societies" (Knoblauch and Löw 2017, 16), the historicity of the sociospatial process inquired by the approach becomes a conceptually unescapable issue.

So far, however, the historicity of the refiguration of spaces has only been addressed implicitly. By assuming the "acceleration of social life" as an overall empirical assessment, Hubert Knoblauch and Martina Löw (2017, 1) emphasize their conceptual commitment to Hartmut Rosa's $(2005,11)$ thesis on social acceleration as a historically speedier-than-before orientation of social change that particularizes “our present society." Indeed, Rosa's temporal diagnosis also corroborates alternative conceptualizations of the relationship between time and the production of space by authors who use the "refiguration of spaces" approach (Weidenhaus 2015; Christmann 2015; Knoblauch 2017). 
A second indirect allusion to the historicity of the refiguration of spaces substantiates the conceptual construction of the approach. Its authors are interested in threefold spatial changes from the last fifty years regarding bodily and materially mediated communicative action amid specific post-war societal processes that social theory termed "modernity" and later "globalization" (Knoblauch and Löw 2017, 6-11). The multiplication of both contexts of meaning ("polycontexturalization") and the forms of communication ("mediatization") go alongside "the embedment of social units, such as families, neighborhoods and religious communities" into increasing physical and digital mobility circuits ("translocalization") (Knoblauch and Löw 2017, 11-14). Based on Norbert Elias' figuration concept, the authors propose that polycontexturalization, mediatization, and translocalization are processes of spatial refiguration, or the spatial transformation of the "centralized figuration" that characterizes "modern society" (Knoblauch and Löw 2017, 10).

Both implicit references to historicity suggest that the refiguration of spaces is a linear transformation of a relatively slow past into an accelerated present. It does not matter that "social acceleration" implies a possible "frantic standstill" (Rosa 2005, 460). Indeed, according to the authors of the "refiguration of spaces" approach, not even COVID-19 has changed the "general spatial pattern" in focus (Löw and Knoblauch 2020, 222), although "particularly the western world" will "witness a refiguration" of the "established "interaction order" (Goffman 1983) after quarantine (Löw and Knoblauch 2020, 224). Therefore, it is more precise to propose that the model of historicity implicit in the production of space from the 1970s is one of poly-linear acceleration. Its linearity is as multiple as the communicative actions through which spaces have been refigured.

In the wake of two former critical appraisals of approaches to historicity in the sociology of relational space from the 1950s (Frehse 2017; 2020), this chapter addresses the operational consequences inherent in the historicity model of polylinear acceleration on the empirical reach of the "refiguration of spaces" approach. I argue that this model restricts the mobilization of the approach in empirical fields marked by alternative models of historicity. This especially applies to empirically given patterns of spatialization implicit in social interaction: their temporal immediacy is underpinned by a plurality of social temporalities of a historical nature that challenge the unicity of the poly-linear acceleration model.

In order to demonstrate this proposition within the limits of this chapter, I focus on Knoblauch and Löw's hypothesis on the increasing physical and digital mobility implicit in translocalization. I firstly confront this statement with a sociospatial phenomenon that has increasingly characterized São Paulo, the biggest Latin American city, precisely within the time span curtailed by the "refiguration of spaces" approach: homelessness. More specifically, in the second section, I apply a specific dialectical-cum-phenomenological methodology to the historicity implicit in the patterns of spatialization of bodily and materially mediated (non-)verbal interaction by specific homeless pedestrians in São Paulo's pre-COVID downtown streets and squares in order to depict what the underlying model of historicity discloses about the production of public space in the city. Hence, what comes to the conceptual 
forefront is a historically at the very least bitemporal process of dialectical space (re)production, which transcends the implicit poly-linear acceleration of the refiguration of space. This model conclusively signals to three contributions of this chapter for expanding the empirical plausibility of the "refiguration of spaces" approach.

\section{Homelessness as empirical counterevidence to increasing mobility}

Since the 1980s, rough sleeping has been added to the social-political, geographical, and sociological agendas in cities as diverse as Los Angeles, New York, London, Toronto, Paris, São Paulo, Singapore, and Melbourne. Given the continuously expanding urban palette, homelessness has become a worldwide issue (Bainbridge and Carrizales 2017), often in connection with other materializations of housing that policyholders qualify as "inadequate": temporary shelters, evictions, and "illegal campsites" (FEANTSA 2015). Particularly in São Paulo, roughly 45\% of the almost 24,500 homeless people identified as such (2019), among the city's 12.5 million total inhabitants are demographically settled in the city's downtown district Sé.

International scholarship on the bodily dimension of homelessness - in other words, on the interference of simultaneously physical and symbolic human skills on the phenomenon at stake-often alludes to "mobility" in order to heighten the role played by physically moving through urban public places on a regular basis in characterizing homeless people (see, for example, Kawash 1998; Mitchell 2005; Frangella 2009; Blomley 2010). This conceptual association comes as no surprise if we remember that the homeless' mobility is often explained with the aid of empirical references to police repression against these people's daily physical presence in streets, squares, parks, and other places.

Given that "in recent decades" (Clarke and Parsell 2018, 1952) the surveillance and punitive practices in Anglo-American cities have co-developed with policies aimed at turning downtowns into "sites of consumption and leisure," it becomes conceptually tempting to pair the physical mobility implicit in homelessness with the historical increase in digital and physical mobility that is addressed by the "refiguration of spaces" approach-and hence, with its implicit model of poly-linear acceleration.

However, things are conceptually more complex when we focus on one definite bodily and material evidence of homelessness in the pre-COVID São Paulo downtown streets and squares during the shop opening hours: the "maloca" (Figure 4.1), a popular Brazilian label for for "indigenous hut," which is used by homeless people in Brazilian cities to identify their daily face-to-face gatherings in public places (Frangella 2009, 153, 184; Frehse 2013, 119-122; Robaina 2015, 328-330)-at least until corona entered the scene.

There are still no research data about these gathering-malocas in COVID São Paulo-meaning the time between the municipality's official closure of commercial and service establishments as well as parks (March 2020) and now (July 2020). But the pre-COVID central public places daily hosted uncountable gatherings of 


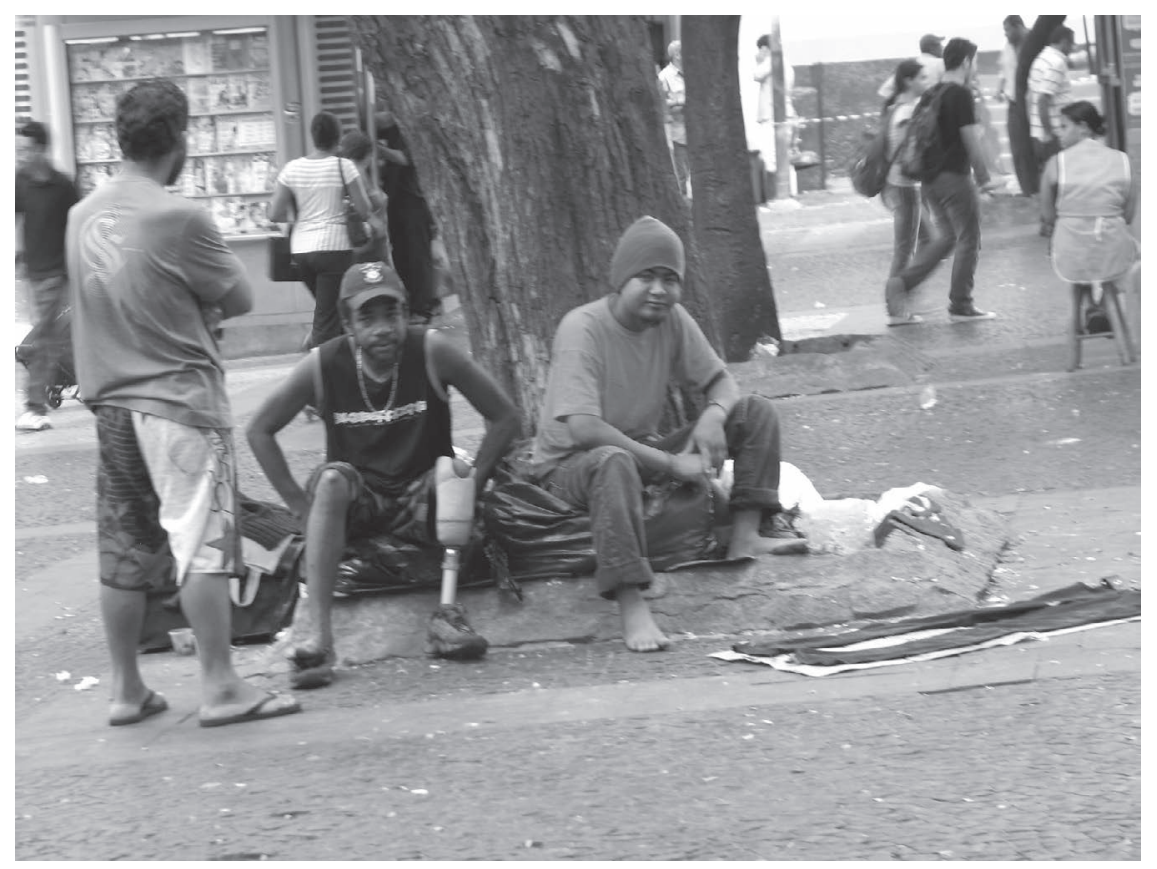

FIGURE 4.1 Research clues of a gathering-maloca in São Paulo's cathedral square on a Wednesday afternoon, 20 April 2011

Source: Photo by Fraya Frehse/private collection

at least three homeless men, less frequently women, and more rarely children, surrounded by specific material goods. These ranged from plastic bags and backpacks, blankets and sometimes mattresses or pillows, to trolleys and buggies as well as second- or third-hand cardboard boxes and chairs from surrounding rubbish bins, in addition to second-hand clothes and accessories such as caps and sunglasses, umbrellas, shoes, and clandestine merchandise from the discreet clandestine fair ("feira do rolo") nearby (Frehse 2014, 254). All of this coexisted in these essentially symbolic places devoid of objective physical borders, which the homeless used to call malocas, together with low-cost variations of the sugar-cane drink "cachaça" and tobacco alongside marijuana cigarettes, cocaine stones, and crack pipes. It did not matter that mobile police stations lay only a few meters away, or that mobile policemen and women patrolled the sites daily amid the to and fro of other, more or less mobile pedestrians.

This empirical evidence undeniably challenges scholarly international commonsense about the prevailing physical mobility of homeless people in urban public spaces. The challenge becomes conceptually even more vexing when we consider that the number of regular homeless gatherings in São Paulo's downtown streets and squares was also remarked on in the first studies about begging and homelessness in the city. Until the 1970s, rough sleepers were socially labelled "beggars" (Stoeffels 
1977) and physically remained in what have been referred to as spots ("pontos") of São Paulo’s downtown public places. Individual begging (Stoeffels 1977, 123), rough sleeping (Vieira, Bezerra, and Rosa 1992, 49), resting, or "the earning of subsistence" (Simões 1992, 37) were safe due to group strategies (Stoeffels 1977, 123). Hence, it makes sense that in the early 1990s the spots were recognized as "the preferred gathering locales of the street population" (Simões 1992, 37).

All in all, what we observe is not increasing mobility but rather persistent physical immobility amid mobility. This state of affairs has persisted despite the fact that the São Paulo municipality abolished park benches and any other functional seating devices from downtown streets and squares in 2007.

Therefore, homelessness in pre-COVID São Paulo's downtown public places is clearly useful for the purposes of this chapter. As we will see with the aid of a fourstep methodological approach that brings together Erving Goffman and Henri Lefebvre, the empirical assessment in focus contradicts the hypothesis of increasing mobility that underpins the "refiguration of spaces" approach due to the model of historicity implicit in the patterns of homeless interaction that become spatial in the malocas.

\section{The production of space through the historicity implicit in the spatialization of interaction}

My methodological sensitivity to what I term spatialization patterns of social interaction stems from Erving Goffman's analysis of the temporality and spatiality of faceto-face interaction (see Frehse 2020, 10-12). He focused in analytical terms on the (temporal) immediacy of (spatial) situations comprising bodily and materially mediated non-verbal and verbal conduct - in other words, communicative rules that are respectively forged in the individuals" "body idiom," put into action by means of material objects in places (Goffman 1963, 33-42), and shared by groups of "adherents" (Goffman 1967, 49). Thereby, this author drew sociologists' attention to the symbolic regularities involved in (non-)verbal interaction becoming spatial-and hence, for example, bringing to the conceptual forefront "regions" and "territories" (Goffman 1959; 1963; 1967; 1971; Frehse 2020; 2021; forthcoming/2021).

From this standpoint, the spatialization of interaction implies the temporally immediate production of various social orderings of space-or spatialities-within the spatial boundaries of social interaction-or situations (Frehse 2020, 8, 11). Hence, my search of spatialization patterns of interaction becomes operational: once the patterns of (non-) verbal interaction are analytically identified, we may address the spatialities that humans produce immediately by means of these same bodily and materially mediated interactions.

In this methodological step, the historicity of the spatialities of interaction enters the analytical scene- and Goffman leaves it. Although admitting that not everything that occurs (immediately) "in a situation" is "of" it, his focus was on the interactional dimension of what I term spatiality - in his words, the "situational aspect of a situated activity" (Goffman 1963, 22; 1983, 2; original emphasis). 
Therefore, it comes as no surprise that the historicity of interaction is absent from Goffman's work (Frehse 2020, 21), and also from recent international scholarship that mobilizes his space concepts (Frehse 2021).

But the historicity implicit in the spatialization of interaction remains underexplored in other current sociological strands as well. One relatively recent historicalsociological approach to historical transformations in patterns of interaction (Baur 2005, 100, 103-107) emphasizes the causality of timing, the form and duration of these changes rather than what is of interest in this chapter: the entanglements of historical temporalities within the temporally immediate spatialities of interaction. Nevertheless, even that approach remains rare in a scholarly landscape that usually privileges the temporal immediacy of interaction. The same applies to the debate on the production of space (Frehse 2020; for an exception, see Frehse 2017).

Subsidized by a former empirical demonstration that the historicity of the empirically inquired sociospatial processes influences their production (Frehse 2017), my specific statement here is that the historicity of the spatialities of interaction by the homeless pedestrians in São Paulo's pre-COVID malocas interfered by means of these homeless bodies with the production of space in the city's downtownand hence also, in theoretical terms, with the sociospatial processes addressed by the "refiguration of spaces" approach. What remains open is the "how" of this interference.

In search of an answer, I again (Frehse 2014; 2017) turn to Henri Lefebvre's three-step regressive-progressive method (2001, 73-74). Although developed in the early 1950s, it remains unique in combining the ethnographic "description" of social relations and material elements in various empirical fields with the "analytical-regressive" depiction of their historical dates, or ages-in other words, the specific temporal moments of social history in which they emerged (Lefebvre 2001, 65-66). The aim is a "historical-genetic" interpretation of what their historically more or less contradictory temporal coexistence discloses in dialectical terms about wider social transformations - and particularly about phenomenological and historical trends in the "production of space" (Lefebvre 2000; Frehse 2020, 12-15). Given that homeless people are not subjects of historicity in Lefebvre's sense-which stems from Marx's reflections on the historicity of mankind-and that Lefebvre addressed neither social interaction nor its spatialities (Frehse 2017, 518), I freely adjust his method to my aim of describing, analyzing, and interpreting how the historicity of the spatialization patterns of social interaction interferes with the production of space.

Therefore, in theoretical terms, this interference is dialectical instead of causal. Without resorting to historical determinism, Lefebvre $(2001,22)$ argues that "the historical" persists and acts upon "the actual" everywhere, given that "the society in act, the result and product of the social activities" is "inscribed" in space through the mediation of (past) time. Hence, "the space generated by time is always actual" (Lefebvre 2000, 131). Methodologically, this implies privileging the analytical tool that I term historical dating rather than the pair chronology-timing, which is employed in historical sciences and historical sociology in search of causality chains 
(Baur 2005, 81-83; Hergesell 2019, 56-58; Hergesell, Baur, and Braunisch 2020, 276-280).

As we will see from this point forward, the overall methodological outcome of this singular theoretical encounter between Goffman and Lefebvre is a regressive-progressive procedure that descriptively departs from (i) rules of (non-)verbal interaction in order to analytically depict (ii) their spatialities, whose historical dates may then (iii) be scrutinized with the aim of (iv) interpreting what the underlying historicity discloses about the production of space. When applied to my ethnographic fieldnotes and interview transcriptions about one maloca in particular that regularly took place in São Paulo's cathedral square (Praça da Sé) from February to July 2013, this approach evinces a peculiar historical poly-temporality that mediated the bodily (re)production of an immobile public space by the preCOVID São Paulo homeless amid their own and other pedestrians' mobility in the city's downtown.

\section{Step 1: descriptively identifying rules of (non-verbal) interaction}

I was introduced to the sugar-cane drink maloca on the first day of my thirteenmonth period of systematic fieldwork in the five major squares of downtown São Paulo during the shop opening afternoons (2-6 p.m.) on Mondays and Fridays. Based on (non-)verbal interaction with twenty-seven maloca members during participant observation of the maloca, and with ten members during in-depth interviews "in" the same setting, I grasped a social structure composed, on the one hand, of a nucleus ranging from three to eight homeless pedestrians (at least three men, at maximum five men and three women). They physically stayed on a regular basis either at or around one specific spot around the low walls that separated the square's gardened area from the cathedral's rectangular forecourt. On the other hand, the maloca comprised a periphery of mobile (ex-)homeless pedestrians, who used to visit the nucleus somewhat regularly (of the aforementioned twenty-seven pedestrians, ten were homeless and seventeen ex-homeless and/or loiterers). Visits occurred especially on Friday afternoons, when a samba circle ("roda de samba") enlivened the maloca with the aid of drums improvised out of cans and wooden or paper cardboard boxes. On workdays, the gathering regularly vanished from the square after 6 p.m. This was when the stores and government agencies started to close their doors and the public shelters started to open theirs. Hence, passers-by and non-passers-by (Frehse 2014, 252) such as the maloca members made their way to their (rough) sleeping places.

The social structure at stake became analytically visible to me due to six rules for what I have termed body conduct (Frehse 2017, 518). It was by means of these patterns that the reproduction of spatialized (non-)verbal interactions took place in the maloca, at least on workdays:

1 The gathering's bodily and material layout stemmed from the aforementioned temporally regular physical behavior of immobility amid mobility, which the maloca members shared in the square; 
2 As for the maloca's access to (limited) material resources, a straightforward division of labor aimed at the acquisition of food for all. Twice a day, two nucleus members departed in order to either beg for food or to identify sources of collective food distribution;

3 There was a similarly straightforward collective division of gains. Any money obtained by the members was converted into cachaça or marijuana contributions to the maloca;

4 The collective attempt to protect the members' individual stuff peculiarly condenses the former three rules. The (only sparsely extant) personal belongings of each member were not to be touched by anyone, and the nucleus tried to defend them jointly-depending on their degree of soberness;

5 As for the maloca's intramural sociability, there was the interactional valorization of identity labels regarding specific family members. Each nucleus member had a family-role label: "father," "mother," "sister," "brother," "sister-" and "brotherin-law," and "mistress." Moreover, the maloca hosted a variety of these nuclear families (the members verbally informed me of at least four). By the same token, the maloca's female members verbally conveyed that they wished to be "married" to male members instead of being single — a condition they equated to socially despised prostitutes;

6 Regarding extramural sociability, there was the members' (non-)verbal welcoming of (non-)passing-by visitors like myself and other passers-by-but never the police! When arriving for the first time, visitors were invited to eat and drink for free, mainly at a Friday afternoon chicken barbecue that was improvised around the square's low walls with a whole chicken and a gas cooker.

\section{Step 2: analytically identifying spatialities within the rules of interaction}

As to the spatialities of the six patterns of body conduct, they are twofold:

1 The (non-)everyday: The maloca members mobilized the rules at stake in the temporal immediacy of situations that were reproduced at least on workdays. This circumstance suggests that their spatiality is "the everyday" as the spatial realm of socially repetitive and doxic uses of cyclic and linear rhythms (Frehse $2020,8)$. Indeed, the maloca's physical size in the square also varied on a daily basis: its spatially systolic-diastolic feature repeated itself indefinitely. Simultaneously, however, these spatial repetitions did not follow cyclic or linear rhythms. Instead, they applied to the socially forged propensity for physical immobility amid mobility, for the collective search for food, for money gains, for the protection of belongings, and for socializing within the maloca's imprecise spatial borders. Temporal routines did not apply to the factual effectiveness of this propensity, which was completely arbitrary: the maloca's bodily and material reproduction depended on the individual degree of soberness to the also random repressive initiatives by the police. Therefore, I consider the dialectical (non-) everyday a decisive spatiality of the six rules of body conduct. 
2 The factual(-imaginary) social space of marginalization(-integration): In sociological terms, the rules suggest that each maloca member was factually alone within the joint marginal social space that encompassed them altogether due to common biographical traits (mental health conditions, family and migration background, socioeconomic poverty). At the same time, however, the patterns were framed within an alternative joint spatiality concerning the maloca members' positions in social space. Their factual social positions did not prevent them from imagining, that is to say, mobilizing their intrinsically human ability to symbolically produce images, which are "forms" of "the imaginary" (Lefebvre 1980, 240). From this theoretical viewpoint, the imaginary is one historically specific "relation between the (reflected, subjective) conscience and the real as such" - in other words, "the immediate" (Lefebvre 1980, 56, 42)—which is "mediated" in symbolic terms by the massive, industrially driven production of images that prevails in post-war capitalism (Lefebvre 1980, 56). Therefore, the factual social space of social marginalization that involves the maloca's members simultaneously encompasses an imaginary dimension of social integration: a large family that comprises indefinite smaller, nuclear families and acquainted visitors. This essentially symbolic space of belonging socially integrated the maloca members in a way that was denied to them by the social space where they were located in sociological terms due to social indicators. Both spatialities coexisted dialectically. It does not matter that the family compounds were contingent, stemming from affective affinities between daily (re)established heterosexual couples, solo members, and passing-by acquaintances. Under the aegis of such affinities, the rules of interaction between all of these pedestrians were quickly reordered within a categorial set of parenthood terms that bore its own sociospatial margins: "wives" despised female members "without a family" as being socially marginalized "mistresses."

\section{Step 3: analytically dating the spatialities of interaction in historical terms}

Regarding this methodological phase, a backward reading (Baur 2005, 84) of the corresponding social-scientific and historical literature is especially suitable:

1 As for the (non-)everyday, studies on various empirical objects implicitly offer empirical evidence of the historically persistent (non-)everyday routine of the poor in São Paulo's streets and squares: the experience of homeless children therein during the 1990s (Gregori 2000); the corporality of homeless adults during the 2000s (Frangella 2009); the bodily uses of this city's downtown streets and squares by pedestrians in different historical moments ranging from the colonial and slaveholding early nineteenth century to the 2010s (Frehse 2011; 2017; 2018a; 2018b); the historical contradictions implicit in conceptually mobilizing the everyday in order to understand the "conscience of the ordinary man" in early twenty-first-century Brazil (Martins 2008). These data testify to a historically long-standing routine that is made up of the temporally 
and spatially aleatory character of at least two sociospatial traits of São Paulo's downtown public places, starting in the officially post-slavery late nineteenth century (i.e. as of 1888). I am referring, on the one hand, to police repression regarding social activities by the poor (street vending, loitering etc.) and, on the other hand, to the situational components implicit in these pedestrians' (non-) verbal interactions with other pedestrians and workers or inhabitants of the surrounding buildings.

These findings not only confirm that, as pioneered by Lefebvre (1968), the everyday is a particular historical product, which emerged in the modern late nineteenth-century capitalist world, but also indicate that the (non-)everyday of the maloca on workdays dates back in historical terms to the late nineteenth century.

2 As for the factual(-imaginary) social space of marginalization(-integration), crucial historical dating references stem from a wider anthropological debate about family structure and female identity among the poor in urban Brazil as of the 1980s (Corrêa 1982; Sarti 2003, 19). This literature addresses human types whose factual marginalized social space owes everything to the fact that they lack the means that assign power, wealth, and prestige to individuals in a capitalist society (Sarti 2003,19-20). At the same time, the studies suggest that the maloca's imaginary large family of families and visitors can be accounted for by the spatially far-reaching role played by the family as a distinctive moral set of consanguinity and affinity relations among the urban poor in São Paulo's peripherical districts at least since the 1980s. Grounded on a patriarchal and hierarchical structure within which the "whole" prevails over its "parts" - the individual members (Sarti 2003, 20) - and in which the woman holds a subordinate position (Sarti 2003, 20), the family's symbolic reference is a hierarchical moral code that transcends the "house" (casa), which has been a referential social and physical space in Brazil since colonial times (for a summary, see Frehse 2013,102). Comprising neighborhood and work relations, too, this code "expands to the outside, and configures a system of values that impacts the ways in which the poor conceive and face the social world" (Sarti 2003, 21).

In light of these references, the maloca's social space, which is factually marginalized and imaginarily integrated, originated in the 1980 s.

\section{Step 4: interpreting the production of space through the historicity implicit in the spatialities of interaction}

Given that both historical dates refer to spatialities of (non-)verbal interaction, they necessarily interfered with the bodily and material layout of São Paulo's cathedral square during the first semester of 2013. During the maloca's existence, the immobility amid mobility that characterized that public place was also due, on the one hand, to a (non-)everyday invigorated by the temporal coexistence between the post-slavery nineteenth and the early twenty-first centuries; and, on the other hand, to a factual(-imaginary) social space constantly enlivened by values of the 1980s regarding poor São Paulo families. 
Hence, we notice one entanglement of historical temporalities. The first one is more than a century old, whereas the second is aged almost forty years. Their empirical simultaneity in the same square conceptually suggests that the sociospatial phenomenon maloca bears a bitemporal historicity model at minimum - that is to say, a historical poly-temporality. Now we may at last address the "how" of the interference. The historicity model indicates that during the maloca's existence, São Paulo's cathedral square was reproduced in bodily and material terms, on workdays, by means of the spatially productive temporal coexistence of at least the late nineteenth and the late twentieth centuries within the temporally immediate interactions of the square's (im)mobile homeless pedestrians. If we follow Lefebvre's $(2001,74)$ suggestion that the historical-genetic interpretation of the previously dated structures depends on assessing their transformations against the background of the further (internal or external) development and these structures' subordination to the overall structures (Frehse 2017, 517), a methodologically tempting reference of such an overall process (Lefebvre 2001, 74) is the production of urban public space within the aforementioned societal processes addressed by the "refiguration of spaces" approach.

From this standpoint, the production of public space in pre-COVID São Paulo was a bodily and materially reproductive process spurred, among other things, by two spatialities of interaction whose (temporally immediate) production (i.e. spatialization) was due to the historical poly-temporality of the (non-)verbal interaction of homeless pedestrians in public places such as Praça da Sé. It was a sociospatial process of a dialectical nature, indeed a bodily (re)production of space underpinned in historical terms by a time-span that ranged from the late nineteenth to the early twenty-first century, and which temporally coexisted with the poly-linear accelerated vigor of mobility that has refigured this very space along with several others since the 1970s.

\section{Conclusion: the relevance of historicity}

Hence, we may return to this chapter's original objective. In order to increase the empirical plausibility of the "refiguration of spaces" approach, it would be advisable to turn the historicity models implicit in the production of space into an analytical issue. My regressive-progressive approach to the historicity of the patterns of spatialization implicit in the social interaction of particular homeless pedestrians in the pre-COVID São Paulo downtown public places demonstrated in a synthetic way that (i) space is produced by means of spatialities of social interaction that bear various historical dates; (ii) different models of historicity may simultaneously underpin one and the same societal process of space production; (iii) no societal process of space production is overarchingly linear in historical terms. As a whole, these findings show that specific historicity models interfere in various ways with empirically given processes of space production, and hence with their conceptualization. The models implicit in the spatialized interactions that empirically underlay the (im)mobile sugar-cane drink maloca indicate a dialectical (re)production of a persistent (im)mobile public space rather than the linear refiguration of an increasingly mobile one. 
In light of these conceptual outcomes, a second contribution of this chapter to the "refiguration of spaces" approach may come to the fore. It would be worth engaging with dialectical approaches to the production of space in greater detail. Whether or not the dialectical method is "unique in addressing the multiple determinations of what is concrete" (Martins 2013, 74) should be of interest to a theory that addresses the spatial dynamics of contemporary societies. The aforementioned three conceptual findings of my method, for instance, indicate an absolute historical diversity within the temporally both immediate and simultaneous production of coexisting diverse spaces. Alternative temporal patterns may thus conceptually emerge and enrich the figurational understanding of spatialization processes.

This chapter's third and last input into the refiguration of spaces particularly concerns the relationship between homelessness and the production of space. A historically sensitive approach to the spatialization patterns of social interaction offers alternative findings to this debate. Instead of a commonsensical "social problem," homelessness is a sociospatial process, a specific way of producing (public) space within the wider set of spatial changes of the last fifty years encompassed by the "refiguration of spaces" approach. In pre-COVID São Paulo, the vigor of the immobility amid mobility of the homeless testifies to the fact that surely for economic, but also for sociocultural reasons related to the historicity of the bodily (re)production of public space by homeless pedestrians, mobility as a spatialized pattern of interaction was never fully established among homeless people in the city.

But what can be said about post-COVID São Paulo? In light of the epidemiologic intensity of COVID in this city, we could at first glance expect that the city's daily (im)mobile gatherings of homeless pedestrians have disappeared, thus confirming the aforementioned refiguration of the established interaction order. However, things are again more complex than that. The sociopolitical combination of a long-standing social inequality with an unprecedented social-political irresponsibility, which has recently prevailed in Brazil, implies that the current São Paulo streets and squares are increasingly the home of whole families. Therefore, although new spatialization patterns of interaction are certainly underway, they are supported by vivid reproductive rules. Public space continues to be (re)produced bodily.

\section{Note}

1 This research received grants from the Brazilian National Research Council (from 2018), the Alexander von Humboldt Foundation (2019), and the Centre of Latin American Studies of the University of Cambridge (2020). All translations from languages other than English are my own.

\section{References}

Bainbridge, Jay, and Tony Carrizales. 2017. "Global Homelessness in a Post-Recession World.” Journal of Public Management \& Social Policy 24 (1): 71-90.

Baur, Nina. 2005. Verlaufsmusteranalyse. Wiesbaden: VS Verlag. 
Blomley, Nicholas. 2010. “The Right to Pass Freely: Circulation, Begging, and The Bounded Self." Social \& Legal Studies 19 (3): 331-350.

Christmann, Gabriela B. 2015. "Das theoretische Konzept der kommunikativen Raum(re) konstruktion." In Zur kommunikativen Konstruktion von Räumen, edited by Gabriela B. Christmann, 89-117. Wiesbaden: Springer VS.

Clarke, Andrew, and Cameron Parsell. 2018. "The Potential for Urban Surveillance to Help Support People Who are Homeless: Evidence from Cairns, Australia." Urban Studies 56 (10): 1951-1967.

Corrêa, Mariza, ed. 1982. Colcha de Retalhos. São Paulo: Brasiliense.

FEANTSA (Fédération Européenne des Associations Nationales Travaillant avec les SansAbri). 2015. "ETHOS Typology on Homelessness and Housing Exclusion." www. feantsa.org/spip.php?article120\&lang=en.

Frangella, Simone. 2009. Corpos Urbanos Errantes. São Paulo: Annablume/FAPESP.

Frehse, Fraya. 2011. Ô da Rua! São Paulo: Edusp.

Frehse, Fraya. 2013. "A rua no Brasil em questão (etnográfica)." Anuário Antropológico 38 (2): 99-129.

Frehse, Fraya. 2014. "For Difference 'in and through' São Paulo: The Regressive-Progressive Method." In Urban Revolution Now, edited by Lukasz Stanek, Ákos Moravánszky, and Christian Schmid, 243-262. Farnham: Ashgate.

Frehse, Fraya. 2017. "Relational Space Through Historically Relational Time—In the Bodies of São Paulo's Pedestrians.” Current Sociology Monograph 65 (4): 511-532.

Frehse, Fraya. 2018a. "On Regressive-Progressive Rhythmanalysis.” In Perspectives on Henri Lefebvre, edited by Jenny Bauer and Robert Fischer, 95-117. Berlin: De Gruyter.

Frehse, Fraya. 2018b. “On the Everyday History of Pedestrians' Bodies in São Paulo's Downtown amid Metropolization (1950-2000)." In Urban Latin America, edited by Bianca Freire-Medeiros and Julia O'Donnell, 15-35. London: Routledge.

Frehse, Fraya. 2020. "On the Temporalities and Spatialities of the Production of Space." SFB 1265 Working Paper No. 4. doi: 10.14279/depositonce-9492.

Frehse, Fraya. 2021. "Erving Goffman's Sociology of Physical Space for Architects and Urban Designers." In The New Urban Condition, edited by Tom Avermaete, Leandro Medrano, and Luiz Recamán, 73-85. New York: Taylor \& Francis/Routledge.

Frehse, Fraya. Forthcoming/2021. "Concepts of Space (Region, Territory, Frame)." In GoffmanHandbuch, edited by Robert Hettlage and Karl Lenz. Berlin: J.B. Metzler.

Goffman, Erving. 1959. The Presentation of Self in Everyday Life. New York: Anchor Books.

Goffman, Erving. 1963. Behavior in Public Places. New York: The Free Press/ Collier-Macmillan.

Goffman, Erving. 1967. Interaction Ritual. New York: Anchor Books.

Goffman, Erving. 1971. Relations in Public. New York: Harper Colophon Books.

Goffman, Erving. 1983. "The Interaction Order." American Sociological Review 48 (1): 1-17.

Gregori, Maria F. 2000. Viração. São Paulo: Companhia das Letras.

Hergesell, Jannis. 2019. Technische Assistenzen in der Altenpflege. Weinheim: Beltz Juventa.

Hergesell, Jannis, Nina Baur, and Lilli Braunisch. 2020. "Process-Oriented Sampling." Canadian Review of Sociology 57 (2): 265-285.

Kawash, Samira. 1998. “The Homeless Body.” Public Culture 10 (2): 319-339.

Knoblauch, Hubert. 2017. Die kommunikative Konstruktion der Wirklichkeit. Wiesbaden: Springer VS.

Knoblauch, Hubert, and Martina Löw. 2017. "On the Spatial Re-Figuration of the Social World." Sociologica 11 (2): 1-27. doi: 10.2383/88197.

Lefebvre, Henri. 1968. La vie quotidienne dans le monde moderne. Paris: Gallimard.

Lefebvre, Henri. 1980. La présence et l'absence. Paris: Casterman. 
Lefebvre, Henri. 2000. La production de l'espace. Paris: Anthropos.

Lefebvre, Henri. 2001. Du rural à l'urbain, edited by Henri Lefebvre. Paris: Anthropos.

Löw, Martina, and Hubert Knoblauch. 2020. "Dancing in Quarantine: The Spatial Refiguration of Society and the Interaction Orders." Space and Culture 23 (3): 221-225. doi: $10.1177 / 1206331220938627$.

Martins, José de S. 2008. A Sociabilidade do Homem Simples. São Paulo: Contexto.

Martins, José de S. 2013. A Sociologia como Aventura. São Paulo: Contexto.

Mitchell, Don. 2005. "The S.U.V. Model of Citizenship: Floating Bubbles, Buffer Zones, and the Rise of the 'Purely Atomic' Individual.' Political Geography 24: 77-100.

Robaina, Igor. 2015. "Entre Mobilidades e Permanências.” PhD diss., Universidade Federal do Rio de Janeiro.

Rosa, Hartmut. 2005. Beschleunigung. Frankfurt am Main: Suhrkamp.

Sarti, Cynthia. 2003. A Família como Espelho. São Paulo: Cortez.

Simões Jr., José G. 1992. Moradores de Rua. São Paulo: Pólis.

Stoeffels, Marie-Ghislaine. 1977. Os Mendigos de São Paulo. Rio de Janeiro: Paz e Terra.

Vieira, Maria A. da C., Eneida M. R. Bezerra, and Cleisa M. M. Rosa. 1992. População de Rua. São Paulo: Hucitec.

Weidenhaus, Gunter. 2015. Soziale Raumzeit. Frankfurt am Main: Suhrkamp. 